MICHAEL KNÜPPEL

Liaocheng University

michaelknueppel@gmx.net

\title{
OSTIACICA I: REMARKS ON K. RÉDEI'S NORD-OSTJAKISCHE TEXTE (KAZYM-DIALEKT)
}

Keywords: Northern-Ostyak texts, problems of remarks to works and reviews, I. Futaky estate, corrigenda and addenda to K. Rédei's work on Northern-Ostyak

\begin{abstract}
In his miscella the author deals with the problems of scattered notes and remarks on Károly Rédei's work Nord-ostjakischen Texte (Kazym-Dialekt) as well as with several reviews of this work and shows with which difficulties we are still confronted when dealing with all these materials. Indeed, there are still some remarks and corrections to be done on Rédei's work which have been overlooked by all the reviewers, but besides all criticism the work is still worth reading since it is one of the most important collections of Northern-Ostyak texts.
\end{abstract}

In the course of his works on the Altaic elements in Uralic languages the author of the contribution in hand incidentally came in possession of materials from the estate of the famous Uralist and Altaist István Futaky (12.5.1926-21.1.2013). ${ }^{1}$ On some small slips of paper, which were placed in a separatum of Futaky's review (1971) of

\footnotetext{
1 The major part of the estate of Futaky - consisting of familial as well as scientific correspondence and of some documents from the time of his imprisonment in Hungary (including copies from the files of the Office of History regarding his personality) - today it is kept in the Komitat-archive in Nyíregyháza (Szabolcs-Szatmár-Bereg Megyei Levéltár) and has been handed over to this institution by his family. The library of the Göttingian Uralist, FennoUgrist, Hungarologist, Sibirist and Tungusologist was delivered to the Jósa András Museum in Nyíregyháza. Only a small part of his estate has remained in Göttingen and has been transferred to the Department of Manuscripts and Rare Printings of the State and University Library of Göttingen ("Abteilung Handschriften und Seltene Drucke der Niedersächsischen Staats- und Universitätsbibliothek Göttingen”) in 2014 (Knüppel 2016).
} 
Rédei's ${ }^{2}$ work (1968), Futaky noted some remarks on the texts collected by Rédei. ${ }^{3}$ These notes are neither corrigenda nor addenda to the work in question and are clearly intended for some specified but unknown purposes. ${ }^{4}$

Inside an offprint of a review of the same work written by Schiefer (1973) a further slip of paper could be found. This one was added to the separatum by its author. The paginations given in the text on this slip of paper pointing to the published text of Schiefer's review were erroneous and obviously corrected by Futaky.

Also to the reviewed work in question a single typewritten sheet of paper (entitled "Berichtigungen") was added by its author, Rédei, or the publishing house Vandenhoeck \& Ruprecht in Göttingen. This indeed was a sequence of 24 correcting remarks, to which Futaky (1971: 375 ) also pointed in his review. ${ }^{5}$

During the examinations of the two mentioned reviews of Futaky and Schiefer as well as the remarks of Rédei and his underlying work, which can still be seen as one of the most important North-Ostyak text collections, for the author of these lines some further smaller "inelegances" were striking. In the present article, which is considered as the first one of a series, some of the mentioned addenda and corrigenda as well as some further short remarks should be suggested. This should not to be misunderstood as a belated criticism of the otherwise remarkable work of Rédei.

While Futaky's mentioned notes, which have been handed over to the Department of Manuscripts and Rare Printings of the State and University Library of Göttingen („Abteilung Handschriften und seltene Drucke der Niedersächsichen Staats- und Universitätsbibliothek Göttingen") as well as most of Rédei's remarks ("Berichtigungen"), which were inserted in the book by the publishing house, can be ignored, Schiefer's corrigenda and addenda, which seem to be added to the separata of his review only, but not to the journal itself (and therefore are most likely not accessible to the readers) are of interest. Schiefer noted after indication of page and line (p. 226, line 7 from the top of the page, following the subordinate clause): "In diesem Punkt zeigt sich eine syntaktische Neuerung durch russischen Einfluß". Furthermore, Schiefer notes - again after giving page and line (p. 225, line 16 from top): "während Verf. in anderem Zusammenhang (Nyk 60 (1958), S. 429, ${ }^{6}$ worauf er an dieser Stelle nicht zurückkommt) das permische Wort nicht mit dem

\footnotetext{
11.4.1932-17.8.2008.

3 To Rédei's widely noticed work Nord-ostjakischen Texten some further reviews appeared, but do not seem to have found any interest of Futaky: Kont (1968), Schiefer (1968), Schellbach (1969; cf. Rédei 1973), Mikola (1970), Sauvageot (1970), Wigger (1971).

4 Some of the notes obviously served for preparation of the review as we can conclude from the references to an idol ("Götzenbild") that was brought to the museum in 1960 or the note on the terminus for bullet mentioned as "small arrow" ("kleiner Pfeil"). Presumably, the other note had not been used in the review Futaky was going to write.

5 The fact that Futaky (1971:375) in his review criticizes the ommitting observance of the spirant $\chi$ in a paradigm of phonemes: "Hier sei nur auf den störendsten Fehler hingewiesen: auf S. 11 in der Tabelle der Konsonanten fehlt in der Spirantenreihe neben $w$ und $j$ der Laut $x$ (unter $\check{c}$ )", seems to be out of place since this was already corrected in Rédei's "Berichtigungen".

6 Here we find Radanovics (1958).
} 
ungarischen verglichen, sondern es als Entlehnung ins Ostjakische angesehen hat". Following no. 4 (p. 226) finally Schiefer adds as the fifth point:

Charakteristisch für den zeitgenössischen Stand der ostjakischen Lautforschung ist folgende Tatsache: Nach Verf. (S. 10) gibt es ein Phonem / /i/sowohl in der ersten wie in der nichtersten Silbe, jedoch kein Phonem /i/. Nach W. Steinitz dagegen (welcher allerdings den Vokalismus nur von der ersten Silbe erforschte) gibt es in der ersten Silbe ein Phonem / $/$ /, während er in der nichtersten Silbe konsequent i ohne “ schreibt. Näheres hierzu siehe E. Schiefer, Rezension an DEWOS ${ }^{7}$ Lieferung 1-5, Berlin 1966-72 (ca[.] 15 Seiten) erscheint in EFOu $1973 .{ }^{8}$

On the occasion of the proofreading of the work now - by omitting all of the mentioned compilations as well as the "error lists" (technically speaking most of these are printing errors as we can find them in nearly all works - and it is somehow problematic to accuse the author for them) already arranged in the reviews written by Tibor (1970) and Schiefer (1968) - according to the "patterns" of Rédei's "Berichtigungen" the possible complaints can be listed as follows:

p. 34, line 3 from below: read "ru." instead of "or.";

p. 40, lines 14-16 from below: in the case of sewam 'gall bladder' ('Galle des Bären') we most likely have to assume a foreign-language substitution ('fremdsprachliches Ersatzwort');

p. 50, line 12 from the top of the page: it may make some sense to ignore the Russian forms совхоз and бригада, which are well known, but звено 'working group' ('Arbeitsgruppe'), бочка 'barrell, keg' ('Faß') and приёмщик 'receiving clerk' ('Abnahmebeamter') should have been given;

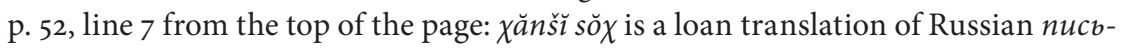
менная доска;

p. 56, line 16 from the top of the page: here meaning 'monstrosity' is given and referred to Russian naкость, but indeed this means 'bawdy person' - by any means in this case the German meaning or translation or some explanations should have been added;

p. 82 , line 8 from the top of the page: instead of лесной for 'forest-spirit' ('Waldgeist'), that, by the way, seems to be quoted by Rédei from another work und which means 'forest-, regarding the forest', леший is more appropriate (even though it belongs to a specific Slavic context);

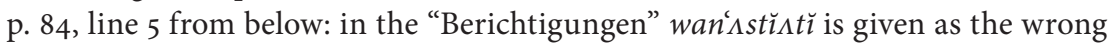
form, but in Rédeis text we instead find wan' $\Lambda$ tĭ $\Lambda t \bar{\imath}$;

p. 104 , line $4 / 5$ from the top of the page: there was no reason to give the Russian meaning (выходной) twice as in line 6 (бродни); in addition, it should have been noted that $\breve{u} \chi o t n \breve{i j} \chi \breve{a} t \Lambda$ is a calque;

p. 114, line 22 from the top of the page: instead of "sich bekreuzen" (= 'to cross oneself') better use "sich bekreuzigen" (correct in the translation on p. 115); etc.

For details, see DEWOS in the References.

8 For details, see Schiefer (1972). 
At this point no endless list of deficiencies could be given and none of the authors shall be accused of some default, rather it should be shown and exemplified, from which difficulties can arise certain mistakes in corrigenda and addenda added and inserted to various works and papers. Although the work of Rédei is still worth reading and it is an impressing work, it stands to reason for describing and correcting additional remarks.

\section{References}

DEWOS = Steinitz W., Sauer G. et al. 1966-1972. Dialektologisches und etymologisches Wörterbuch der ostjakischen Sprache. [Abhandlungen der Deutschen Akademie der Wissenschaften zu Berlin. Klasse für Sprachen, Literatur und Kunst; 15 vols.; vols. 1-3 by Wolfgang Steinitz 1966-1968; vols. 4-5 by G. Sauer et al. 1970, 1972]. Berlin.

Futaky I. (rev.). 1971. Rédei, Károly: Nord-ostjakische Texte (Kazym-Dialekt) mit Skizze der Grammatik. Gesammelt und herausgegeben. Göttingen 1968. - Indogermanische Forschungen 76: 373-376.

Knüppel M. 2016. Der Teilnachlaß von István Futaky (1926-2013) in den Beständen der Abteilung Handschriften und Seltene Drucke der Staats- und Universitätsbibliothek Göttingen. - UngJb 32 [2014/2015]: 259-265.

Kont K. (rev.). 1968. Károly Rédei, Nord-ostjakische Texte (Kazym-Dialekt) mit Skizze der Grammatik. Abhandlungen der Akademie der Wissenschaften in Göttingen. - SovFU 4: 308-309.

Mikola T. 1970. Adalékok a nganaszan nyelv ismeretéhez. - NyK 72: 59-93.

Radanovics K. 1958. Obi-ugor etimológiák. - NyK 60.2: 425-431.

Rédei K. 1968. Nord-ostjakische Texte (Kazym-Dialekt) mit Skizze der Grammatik. Gesammelt und herausgegeben. [Abhandlungen der Akademie der Wissenschaften in Göttingen, Phil.-hist. Kl., III. Folge, Nr. 71]. Göttingen.

Rédei K. 1973. Erwiderung auf zwei Rezensionen. - ALH 23: 231-234.

Sauvageot A. (rev.). 1970. Károly Rédei. Nord-ostjakische Texte (Kazym-Dialekt) mit Skizze der Grammatik. Abhandlungen der Akademie der Wissenschaften in Göttingen Van der Boeck [sic!] \& Ruprecht 1968. - BSL 65.2: 158-159.

Schellbach I. 1969. Eine neue ostjakische Textveröffentlichung. - FUF 37: 373-374.

Schiefer E. (rev.). 1968. Károly Rédei: Nord-ostjakische Texte (Kazym-Dialekt) mit Skizze der Grammatik, gesammelt und herausgegeben von K. R. Abhandlungen der Akademie der Wissenschaften in Göttingen, Phil.-hist. Kl., III. Folge, Nr. 71, Göttingen 1968. - Vir 4: 416-419.

Schiefer E. (rev.). 1972. Wolfgang Steinitz: Dialektologisches und etymologisches Wörterbuch der ostjakischen Sprache. - Études Finno-Ougriennes 9: 161-171.

Schiefer E. (rev.). 1973. Rédei, Károly: Nord-ostjakische Texte (Kazym-Dialekt) mit Skizze der Grammatik. Gesammelt und herausgegeben. Göttingen 1968. - Kratylos 16 [1971]: 224-226.

Tibor M. (rev.). 1970. Rédei, Károly: Nord-ostjakische Texte (Kazym-Dialekt) mit Skizze der Grammatik. - NyK 72: 238-240.

Wigger A. (rev.). 1971. Rédei, Károly: Nord-ostjakische Texte (Kazym-Dialekt) mit Skizze der Grammatik. Göttingen: Vandenhoeck \& Ruprecht 1968. - UAJb 43: 192-193. 